\title{
An Exploratory Study of the University of Oxford Tutorial Method Regarding Its Relationship to Learner
}

\author{
Autonomy
}

Michael K. Ponton

Dept. of Higher Education and Learning Technologies, Texas A\&M University-Commerce

P.O. Box 3011, Commerce, Texas 75429, United States

Tel: 1-757-753-3137Ｅ-mail: Michael.Ponton@tamuc.edu

Paul B. Carr

School of Education, Regent University

1000 Regent University Drive, Virginia Beach, Virginia 23464, United States

Received: May 9, 2020

Accepted: June 18, 2020

Published: July 2, 2020

doi:10.5296/gjes.v6i2.17400

URL: https://doi.org/10.5296/gjes.v6i2.17400

\begin{abstract}
The purpose of this qualitative study was to determine the degree to which the tutorial method used with bachelor's and master's students at the University of Oxford promotes constructs (e.g., desire, resourcefulness, initiative, persistence, and self-efficacy) associated with learner autonomy. As learner autonomy-subsumed under the general field of self-directed learning - has been studied and posited as being an important goal of higher education that can support personally-chosen trajectories long after graduation, instructional methods that promote this psychological undergirding of human agency are needed. The findings reveal a development of actual learning and study skills; however, in support of learner autonomy, the findings reveal a development of self-efficacy in these same skills as well as in learner independence, which is critical to engaging in autonomous learning activities.
\end{abstract}

Keywords: Tutorial, Learner autonomy, Autonomous learning, Self-directed learning 


\section{Introduction}

At the Universities of Oxford and Cambridge, instruction includes not only the ubiquitous lectures and laboratories found in higher education but also uncommon weekly meetings where four or fewer students gather for approximately an hour with a faculty member titled tutor at Oxford and supervisor at Cambridge (Palfreyman, 2008). At these tutorials, students present and discuss their assigned work (e.g., written papers, problem sets) completed in the previous week to support "critical thinking," "reflective-learning," and "deep-learning" (Palfreyman, 2008, p. 41); as Palfreyman asserted, such a tutored student

- takes ownership of content through actively thinking it through

- values questions more than answers

- $\quad$ seeks understanding over rote memorization

- $\quad$ assesses thinking for its clarity, accuracy, precision, relevance, depth, breadth, logic, and significance

- $\quad$ seeks to identify key structural components in thinking

- $\quad$ reads, writes, listens, and speaks critically

- questions the thinking of others and expects his or her thinking to be questioned by others

- thinks for himself/herself while respecting and empathically entering the point of view of others

- locates ultimate intellectual authority in evidence and reasoning. (p. 42)

These weekly exercises require students to independently learn about myriad topics, prepare cogent responses, and engage in critical discourse. Explicitly, tutorials are useful in preparing students to pass degree examinations; implicitly, tutorials are opined as useful in developing independent learners and thinkers.

Ponton (1999) defined autonomous learning as "an agentive learning process in which the conative factors of desire, initiative, resourcefulness, and persistence are manifest" (pp. xiii-xiv; cf. Confessore, 1992). As an agentic action, autonomous learning represents intentional learning in which an individual self-regulates the learning activity by deciding what to learn, how to learn, and whether or not the learning satisfies personal needs via forethought and self-reflection (cf. Bandura, 2006; Ponton, 2016; Zimmerman, Bonner, \& Kovach, 1996). Although tutored students do not have sole discretion regarding what to learn, they nonetheless invoke a great degree of self-regulation in preparing their work and themselves for weekly tutorials.

The purpose of this qualitative study was to determine whether or not the tutorial method used with bachelor's and master's students at the University of Oxford promotes constructs associated with learner autonomy. Upon a cursory review of the tutorial method, this instructional strategy appears to be a viable option in furthering the goal of promoting learner 
autonomy; however, research evidence was needed. Thus, this study was conducted as a matter of exploration in order to gain evidence-based insight into this method of human development.

The question that drove this research was as follows: Do students profess that learner autonomy constructs (e.g., desire, resourcefulness, initiative, persistence, and self-efficacy; Ponton \& Carr, 2016a) are being fostered by participating in the tutorial method? No studies to date have evaluated the tutorial method through the lens of learner autonomy. As dialogue grows regarding instructional strategies that can develop this salient aspect of human agency, research evidence regarding viable methods must inform the discussion. To this end, the study was significant to the field. In addition, as learner autonomy is so important to the development of scholars (Ponton, 2018), professors supporting master's and doctoral programs require an understanding of additional ways to facilitate this development.

\section{Method}

We used a qualitative, naturalistic inquiry design (Patton, 2002) to study the tutorial phenomenon. We interviewed seven students in a natural setting (i.e., a coffee shop) in the city of Oxford based upon their voluntary participation in the study; thus, Institutional Review Board approval from the University of Oxford was not necessary as we collected our data in a public venue. Regent University's Human Subject Review Committee approved the study (both authors were on faculty at Regent University at the time of data collection). We introduced ourselves to potential participants, asked if they were part of our population (i.e., Oxford student with tutorial experiences), provided a description of our research interest, asked if they were interested in participating, and then interviewed them (with audio recording beginning after participant consent was received).

\subsection{Introductory Script}

We offered the following brief script orally to solicit participation:

We are professors from Regent University in the United States. You are being asked to participate in a study that will help educators understand how the Oxford tutorial system enhances a student's capacity to learn. Participating in a brief interview is completely voluntary, will take less than 15 minutes, and poses no known risks to you. In addition, your actual name will not be used in any presentation or publication; rather, your demographic information (program level, major, age, gender, and nationality) will be assigned to a pseudoname. The benefit to participation is helping educators like us to design more effective strategies in order to help our students accomplish whatever they choose in life.

\subsection{Guiding Questions to Participants}

We asked the following questions to the participants:

- Describe the tutorial method?

- Has this method affected your learning capabilities?

- If so, how? 
Probes were provided as necessary to further clarification; however, questions that specifically led to the desired conclusion (i.e., that the tutorial method promotes learner autonomy) were avoided so as to not bias personal narratives. During the interview, we exhibited "empathic neutrality" due to an authentic "understanding, caring, and interest" in the students' lives while remaining "nonjudgmental" (Patton, 2002, p. 53). Demographic items were limited to program level (i.e., bachelor's, master's, and program year), course, age, gender, and nationality.

\subsection{Participants}

The characteristics of the seven participants are presented in Table 1. The sample included (a) four bachelor's (one second-year; three third-year) and three master's students, (b) ages ranging from 19 to 25 years old, (d) five females and two males, and (e) four non-United Kingdom nationals.

Table 1. Student characteristics

\begin{tabular}{|l|l|l|l|l|l|}
\hline Student Pseudoname & Level & Course & Age & Gender & Nationality \\
\hline Yolanda & Master's & $\begin{array}{l}\text { Comparative } \\
\text { Government }\end{array}$ & 22 & F & Netherlands \\
\hline Stella & $\begin{array}{l}\text { Bachelor's } \\
\text { 2nd year }\end{array}$ & $\begin{array}{l}\text { English Language } \\
\text { and Literature }\end{array}$ & 19 & F & U.S. \\
\hline Maria & Master's & $\begin{array}{l}\text { Developmental } \\
\text { Economics }\end{array}$ & 20 & F & Netherlands \\
\hline Rhonda & Master's & Law & 25 & F & Sweden \\
\hline Carl & Bachelor's 3rd year & Engineering & 20 & M & England \\
\hline Jack & Bachelor's3rd year & English Literature & 20 & M & England \\
\hline Henrietta & Bachelor's 3rd year & Theology & 21 & F & England \\
\hline
\end{tabular}

\subsection{Analysis}

The authors discussed the interviews at three different points: immediately after each interview, in the evening after each interview session, and at the end of all data collection. These discussions led to agreement with respect to identified themes.

\section{Findings}

Bachelor's and master's degrees are primarily based upon the passing of examinations (although some programs also require portfolios or dissertations): for example, preliminary exams after the first year and final exams (typically) after the third year for typical bachelor's courses. The examinations are not structured to assess comprehensive knowledge but rather how a student approaches select questions. Students' motivation to engage fully in tutorials is in recognizing that tutorials help prepare them to pass exams.

Tutorials are weekly meetings (1-2 hours) of 2-4 students and a tutor. The exact structure of a 
tutorial is at the discretion of the tutor; however, typically students write a 2,000-2,500 word essay or complete a problem set-problem sets for physical sciences-requiring about 20-25 hours of work. The work is not graded and may or may not be (a) on a topic given by the tutor, (b) submitted to the tutor before the tutorial, (c) critiqued by the tutor before the tutorial, and (d) specifically addressed during the tutorial; however, the student's preparation for the work informs the discussion at the tutorial. The student is expected to engage in oral discussion - that is, debate - regarding his or her position on the topics addressed in his or her work.

Tutorials require students to develop individual arguments with respect to relevant topics, and exams assess how well students are able to provide cogent arguments; admission interviews help to select those students best able to engage in tutorials.

[Tutorials have] been useful in having an oral debate rather than just writing an essay. ... [A tutorial] kind of utilized the information that I gained from the reading on the spot while engaging with peers and the tutor. ... [Tutorials help] you both [to] have a deeper understanding about what they [my ideas] are and how to apply them. (Yolanda)

You really have to turn up prepared ... because the tutor is going to ask you questions and he's [sic] going to really want you to show that you have knowledge in the area. (Rhonda)

You can't just state what other people are saying without thinking about it. (Maria)

It [selecting students who can benefit from tutorials and the extensive work] is part of the admissions process ... nobody gets here by chance. (Henrietta)

In addition to exam preparation, other motivating factors to engage fully in the tutorial are as follows: (a) feeling privileged to have individualized time with a highly reputed scholar, (b) not wanting to waste a highly reputed scholar's time, (c) avoiding embarrassment, and (d) acting as expected to act as an Oxford student (i.e., social norm).

There's a very big sense of not wanting to disappoint your tutor. ... [The tutor] is like some eminent academic, possibly the most important person, and if you turn up with a half-finished set of solutions ... you're wasting ... their extremely valuable time. ... It is fortunate to be able to sit in a room with an academic for maybe 2 hours and just have that personal chance to pick their [sic] brains about how they would solve that problem. (Carl)

Aside from exam preparation, tutorials develop (a) critical thinking skill, (b) critical reading skill, (c) oral argument skill (prepared or extemporaneous), (d) the ability to argue courteously, (e) the ability to read quickly and effectively, (f) efficiency in writing (i.e., the ability to write a concise essay in a short amount of time), $(\mathrm{g})$ confidence in a-f, and $(\mathrm{g})$ learner independence.

I could say that now that I really have had the tutorial experiences it's changed the way I approach my reading. So I'm a more critical reader in general. (Yolanda) 
You're trying to reduce these huge concepts into an essay. (Henrietta)

When I started out [in my course] thinking that writing a 2,000-word essay every week apart from having my readings and my seminars felt a bit overwhelming ... but you really get into a habit of doing this and doing it more efficiently and better. It increases confidence in me when I start working that I know that if someone else were to ask me to prepare an essay I could do it in 20 hours if I had to. (Rhonda)

After 2 years in the [tutorial] system, I've gained the confidence to properly assert an argument in essays. ... I think that if I hadn't had the tutorial system, that would have never come out [of me]. (Henrietta)

You have to learn how to argue with someone, politely. (Stella)

These enhanced skills support the preparation of portfolios and dissertations.

The dissertation, for example, is something that you invent the topic, so it's something that you decide on. But your reading in other [tutorial] areas might, kind of, contribute to other intellectual explorations that could contribute to a dissertation. (Stella)

The negative aspects of the tutorial include (a) an extensive amount of work that sometimes leads to negative student effects (e.g., attrition, eating disorders), and (b) the ability to take a large topic and convince someone else of one's understanding in a brief way.

I don't think there is enough time because you're having to do all of this reading to understand something and then you have to take ... your perspective on it and try to convey that in an ... essay and then move on to the next one. That's kind of frustrating because I don't feel you do as much as you can do. (Henrietta)

[The tutorial] encourages an off-the-cuff, very quick, kind offlashy response.... A lot of people have issues because of the shear intensity of the work. There's a dark side to [the tutorials]. (Jack)

\section{Discussion}

As a mechanism to develop learner autonomy, tutorials strengthen a student's self-efficacy in (a) learning independently, and (b) formulating an individual perspective based upon independent learning. Coupled with an actual development of thinking, reading, writing, and oral expression skills, the strengthening of perceived skills (i.e., self-efficacy; cf. Bandura, 1997) in these domains supports the motivation to engage in autonomous learning. In addition, the development of learner independence also supports the engagement in autonomous learning activities.

Due to the sheer volume of required work, tutorials also promote the development of self-regulatory skills, which is an important construct related to learner autonomy (Ponton \& Carr, 2016b). Students must decide what they need to learn, how to learn it, whether or not sufficient learning has occurred, how to modify learning activities if insufficient (cf. Zimmerman et al., 1996), and how to present their learning and thoughts in an essay. In 
addition to self-regulation, self-control must also be manifest in order for the student to keep focused on goal accomplishment (cf. Rosembaum, 1980) in order to maintain the pace of completing regular assignments.

The participants in this study posited a very utilitarian perspective of the Oxford tutorial: preparation to pass degree examinations. However, the results of this study suggest that the tutorial facilitates the development of numerous psychological constructs that support critical thinking and learner autonomy. As Panton (2008) asserted,

Exams are important: they are the measure of what students have achieved, how sophisticated their thinking has become and how far they have pushed and developed their ideas. They are an important, but not necessarily the most important, marker of achievement. ... The knowledge, the confidence, and the ability to do well, comes from engaging with a subject and pushing your understanding. (p. 111)

In this regard, the tutorial system supports a "higher" education, which is "about preparing people for life-long learning and career retreading, for a life-time contribution to Society as an educated Citizen" (Palfreyman, 2008, p. 10). Strengthening students' abilities to learn, think, express, and act independently has a greater determinative influence and, thus, far greater importance in relation to passing examinations due to its support of the agentic learning necessary to accomplish chosen pursuits throughout a lifetime.

\section{References}

Bandura, A. (1997). Self-efficacy: The exercise of control. New York, NY: W. H. Freeman and Company.

Bandura, A. (2006). Toward a psychology of human agency. Perspectives on Psychological Science, 1(2), 164-180. https://doi.org/10.1111/j.1745-6916.2006.00011.x

Confessore, G. J. (1992). An introduction to the study of self-directed learning. In G. J. Confessore, \& S. J. Confessore (Eds.), Guideposts to self-directed learning: Expert commentary on essential concepts (pp. 1-6). King of Prussia, PA: Organization Design and Development.

Palfreyman, D. (2008). Higher education, liberal education, critical-thinking, academic discourse, and the Oxford tutorial as sacred cow or pedagogical gem. In D. Palfreyman (Ed.), The Oxford tutorial: 'Thanks, you taught me how to think' (2nd ed., pp. 9-45). Oxford, United Kingdom: Oxford Centre for Higher Education and Policy Studies.

Panton, J. (2008). Reflections of an early career-politics tutor. In D. Palfreyman (Ed.), The Oxford tutorial: 'Thanks, you taught me how to think' (2nd ed., pp. 108-113). Oxford, United Kingdom: Oxford Centre for Higher Education and Policy Studies.

Patton, M. Q. (2002). Qualitative research \& evaluation methods (3rd ed.). Thousand Oaks, CA: Sage.

Ponton, M. K. (1999). The measurement of an adult's intention to exhibit personal initiative in autonomous learning (Doctoral dissertation). Retrieved from ProQuest Dissertations \& 
Theses Global. (Order No. 9949350)

Ponton, M. K. (2016). An agentic perspective contrasting autonomous learning with self-directed learning. In M. K. Ponton \& P. B. Carr (Eds.), Autonomous and self-directed learning: Agentic perspectives (pp. 49-61). Chesapeake, VA: Watertree Press.

Ponton, M. K. (2018). Self-efficacy in autonomous learning: A preliminary study of full professors. International Journal of Self-Directed Learning, 15(1), 31-42. Retrieved from http://sdlglobal.com/journals.php

Ponton, M. K., \& Carr, P. B. (2016a). The possible role of higher education in developing learner autonomy: A quantitative exploration. International Journal of Self-Directed Learning, 13(1), 12-25. Retrieved from http://sdlglobal.com/journals.php

Ponton, M. K., \& Carr, P. B. (2016b). Understanding and promoting autonomy in self-directed learning. In M. K. Ponton \& P. B. Carr (Eds.), Autonomous and self-directed learning: Agentic perspectives (pp. 17-31). Chesapeake, VA: Watertree Press.

Rosenbaum, M. (1980). A schedule for assessing self-control behaviors: Preliminary findings. Behavior Therapy, 11, 109-121. https://doi.org/10.1016/S0005-7894(80)80040-2

Zimmerman, B. J., Bonner, S., \& Kovach, R. (1996). Developing self-regulated learners: Beyond achievement to self-efficacy. Washington, DC: American Psychological Association.

\section{Copyright Disclaimer}

Copyright for this article is retained by the author(s), with first publication rights granted to the journal.

This is an open-access article distributed under the terms and conditions of the Creative Commons Attribution license (http://creativecommons.org/licenses/by/3.0/). 